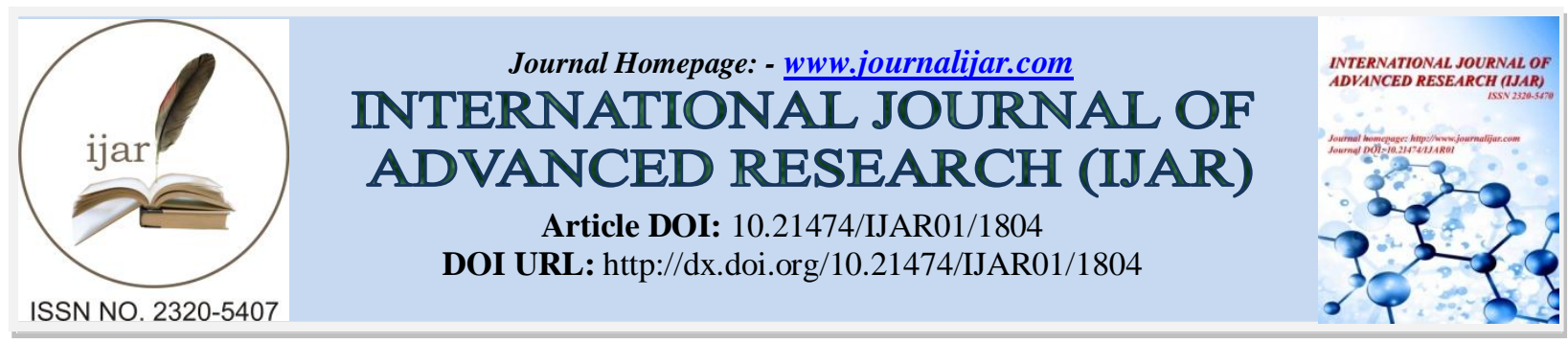

RESEARCH ARTICLE

\title{
RELATIONSHIP BETWEEN PROFILE CHARACTERISTICS OF TEACHERS AND STUDENTS AND THEIR TEACHING LEARNING STYLES.
}

\author{
U. Kiran, T. Prasantha Kumar and T. Gopi Krishna.
}

Department of Agricultural Extension, Agricultural College, Bapatla - 522101 Andhra Pradesh.

\section{Manuscript Info}

Manuscript History

Received: 13 August 2016

Final Accepted: 22 September 2016

Published: October 2016

\section{Abstract}

Agricultural College, Bapatla was purposively selected out of the six Agricultural College in ANGRAU to know the opinions of students and teachers towards teaching-learning styles. The study was conducted by adopting the Ex - post - facto research design. The respondents for the study all final year B. Sc (Ag.) students (90) on rolls as on the date of study in the selected campus. The respondents for the study include all teachers (56) on rolls as on the date of study in the selected campus

Copy Right, IJAR, 2016,. All rights reserved.

\section{Introduction:-}

Teaching is as old as mankind. The ultimate goal of teaching is to achieve mastery in learning and improve the quality of human performance. Davies (1981) stated that successful teaching is nine tenths perspiration and onetenth inspiration. In other words, besides the art of delivery, the teacher must put in lot of hard work for achieving success in teaching. Teaching cannot happen without learners. In fact, teaching and learning are the two sides of the same coin. A student and teacher's general performance in learning and teaching is influenced by various internal and external factors. The opinions of students towards the model class room collected in the present study are of instrumental Value in improving the model classroom conditions there by improving the learning outcome of the student.

\section{Materials and methods:-}

The present Study was conducted by adopting Ex - Post - Facto Research Design. by selecting Agricultural College; Bapatla purposively out of the six Agricultural College in ANGRAU, Andhra Pradesh as it is the oldest College with supposed to be well experienced faculty and required Infrastructural facilities. All Final year B. Sc (Ag.) students (90) and All the 56 Teachers (15 Professors, 20 Associate Professors, and 21 Assistant Professors). were purposively selected. Frequency (f) and Percentages (\%) were used for statistical analysis.

\section{Results and Discussion:-}

Teaching styles of teachers:-

Teaching style was operationally defined as general modes of classroom behaviour teaching method employed characteristics associated with particular teacher the roles the college faculty play, personal traits and archetypal forms and metaphors for teaching. For teaching styles were empirically measured on rating scale consisting of 20 statements over five point continuum viz., strongly agree, agree, undecided, disagree, strongly disagree 5, 4, 3, 2, 1 
respectively and individual respondent scores were arrived at by summing the total score one could get the above said scoring procedure.

\section{Learning styles of students:-}

Learning styles of respondent students was operationally defined as their learning preferences in general as well as their personality dimensions including extra version Vs introversion, sensing Vs intuition, thinking Vs feeling, judging Vs perception over demarcated categories namely independent, dependent, collaborative, competitive, participative and avoidant. The rating scale was used consisting of 14 statements over a five point continuum viz., strongly agree, agree, undecided, disagree and strongly disagree.

\section{Relationship between personal characteristics of a teacher and their teaching styles:-}

Grasha (1996) observed that when faculty rank is considered, the only changes in teaching style that were statistically reliable were those associated with Expert ad Formal Authority styles. Faculty holding the rank of professor tended to employ these two styles more often than did other teachers. In a similar study, he noted that Personal Model style changed very little with the level of courses. The other styles however were used differently in upper-level versus lower-level classes. Participants were less likely to assume the Expert and Formal Authority styles with their advanced undergraduate and graduate courses. In contrast, they were likely to use the Facilitator and Delegator styles in more advanced courses. If upper-level classes attract better prepared student, then the faculty adjusted their styles for the capability level of their students. He further concluded that compared to their male counterparts, women reported somewhat lower scores on the Expert and Formal Authority scales of the Teaching Styles Inventory and some what higher scores on Facilitator and Delegator styles. These differences were statistically reliable.

McColling (2000) found from his study that instructors educational level and type of course taught were related to teaching style.

Reddy (2002) revealed from his study that background and parental occupation of trainers agricultural training institutes were positively associated with their expert teaching style. Whereas, other variables such as age, designation, experience, and number of publications were not associated with expert teaching style of trainers. Similarly, age, background and parental occupation of trainers were significantly associated positively with formal authority style but designation, experience and number of publications were not associated. Background, and parental occupation of the trainers were positively and significantly associated with personal model teaching style and age, designation, experience and number of publications were not associated. Experience was found to have positive and significant association with facilitator teaching style and other variables age, background, designation, parental occupation and number of publications were not associated. In case of delegator style of the trainers, only parental occupation of the trainers was significantly associated positively but only variables such as age, designation, background, experience and number of publications were found to be not associated with the delegator style of the trainers.

It was found from above findings that background, parental occupation, educational level, age, designation, experience of respondents were significantly associated positively with teaching style.

Relationship between profile characteristics of students and their learning styles:-

Schroeder (1993) concluded from their studies that there was relationship between students' learning styles and academic performance. Further they stated that when learning styles were considered in the teaching-learning process, student achievement was enhanced.

Research evidence accumulated around sex differences in learning styles reveal that in most of the studies male and female students have been found almost at par (Schmeck et al., 1977; Schmeck and Ribich, 1978.

Torres (1993) have reported positive relationship with academic performance, as measured by grade point average.

Cano and Porter (1997) and Cano (1999) reported that learning styles had positive relationship with overall success of students in higher education. 
Reddy (2002) revealed that the variable background of trainees was significantly associated positively with reflective observation disposition of the trainees only at .07 per cent level of probability. Other variables parental occupation and learning source utilization were not significantly associated with learning style dispositions.

Relationship between profile characteristics of students and teachers and their teaching learning styles:The correlation coefficient values showing the relationship between selected personal characteristics of students and their learning styles, selected personal characteristics of teachers and their teaching styles.

Relationship between profile characteristics of students and their learning styles:-

Correlation and multiple linear regression analysis were carried out to find out the relationship between independent variables and learning styles.

The relational analysis about students clearly revealed that the computed " $r$ " values of background (0.5176), academic performance (0.6006), opinion towards model classroom (0.7352), perception towards teaching styles (0.7858), learning resources (0.5897), physical facilities (0.8069) and interaction with teachers $(0.7628)$ were found to be positively significant at 0.01 level of probability and the remaining independent variables i.e., gender $(0.0814)$, interaction with co-students (-0.0550) was found to be non-significant with learning styles of respondent students.

The regression analysis revealed that independent variables i.e., learning resources and physical facilities are found to be positive significant with learning styles at 0.01 level of probability. Remaining independent variables were found to be non-significant with learning styles. The value of coefficient of multiple determination $\left(\mathrm{R}^{2}\right)$ was 0.759 indicating that all the independent variables could explain about variation in the dependent variable to the extent of 75.9 per cent. It was shown in Table $1 \& 2$.

Table 1:- Correlation between selected personal characteristics of students and their learning styles of respondent students.

\begin{tabular}{|l|l|l|}
\hline S.No. & Independent Variable & 'r' values \\
\hline 1. & Gender & $0.0814 \mathrm{NS}$ \\
\hline 2. & Background & $0.5176^{\text {*** }}$ \\
\hline 3. & Academic performance & $0.6006^{* *}$ \\
\hline 4. & Opinion towards model classroom & $0.7352^{* *}$ \\
\hline 5. & Perception towards teaching styles & $0.7858^{\text {*** }}$ \\
\hline 6. & Learning resources & $0.5897^{\text {** }}$ \\
\hline 7. & Physical facilities & $0.8069^{* *}$ \\
\hline 8. & Interaction with teachers & $0.7628^{\text {*** }}$ \\
\hline 9. & Interaction with co-students & $-0.0550 \mathrm{NS}$ \\
\hline$* *$ Significant at 0.01 level of probability. & \\
\hline
\end{tabular}

Table 2:- Regression coefficient between selected personal character-istics of students and their learning styles of respondent students.

\begin{tabular}{|l|l|l|l|l|}
\hline S.No. & Independent Variable & $\begin{array}{l}\text { Regression } \\
\text { coefficient }\end{array}$ & Standard error & t-value \\
\hline 1. & Gender & 0.2040 & 1.4082 & 0.14483 \\
\hline 2. & Background & -0.7880 & 1.8534 & 0.4251 \\
\hline 3. & Academic performance & -0.1683 & 1.8993 & 0.0886 \\
\hline 4. & Opinion towards model classroom & 0.0496 & 0.1242 & 0.3993 \\
\hline 5. & Perception towards teaching styles & 0.1949 & 0.1079 & 1.8054 \\
\hline 6. & Learning resources & 0.2970 & 0.0929 & $3.1944^{* *}$ \\
\hline 7. & Physical facilities & 0.7642 & 0.2015 & $3.7926^{\text {*** }}$ \\
\hline 8. & Interaction with teachers & 1.1971 & 0.7697 & 1.5552 \\
\hline 9. & Interaction with co-students & -0.0120 & 0.2763 & 0.0433 \\
\hline
\end{tabular}

** Significant at 0.01 level of probability. 


\section{Relationship between profile characteristics of teachers and their teaching styles:-}

In the case of respondent teachers it is vivid from the table 3 that "r" values of age (0.6325), designation (0.4851), gender (0.3627), academic qualifications (0.5271), teachers' parental occupation (0.6802), teachers experience (0.5712), training received (0.5647), opinion towards model classroom (0.8257), use of teaching aids $(0.4356)$, use of teaching methods (0.7271), learning resources (0.6059), physical facilities (0.6181) and interaction with coteachers $(0.6016)$ were found to be significant at 0.01 level of probability and background $(0.3271)$ was found to be significant at 0.05 level of probability with teaching styles. Remaining independent variable i.e., interaction with students $(0.1201)$ was found to be not significant with teaching styles.

It was gleaned from table 38 regression analysis revealed that the independent variables teaching experience, training received and opinion towards model classroom were found to be significant with teaching styles of respondent teachers at 0.01 level of probability.

The value of coefficient of multiple determination (R2) was 0.801 indicating that all the independent variables could explain about variation in the dependent variable to the extent of 80.1 per cent.

Table 3:- Correlation between selected personal characteristics of teachers and their teaching styles of respondent teachers.

\begin{tabular}{|c|c|c|}
\hline S.No. & Independent Variable & 'r'values \\
\hline 1. & Age & 0.6325 ; \\
\hline 2. & Designation & $0.4851^{* *}$ \\
\hline 3. & Gender & 0.3627 \\
\hline 4. & Academic qualification & $0.5271^{\prime \prime}$ \\
\hline 5. & Background & $0.3271^{*}$ \\
\hline 6. & Teachers parental occupation & $0.6802^{\text {was }}$ \\
\hline 7. & Teaching experience & $0.5712^{* * *}$ \\
\hline 8. & Training received & $0.5647^{* * 9}$ \\
\hline 9. & Opinion towards model classroom & $0.8257^{* 2 *}$ \\
\hline 10. & Use of teaching aids & $0.4356^{* *}$ \\
\hline 11. & Use of teaching methods & $0.7271^{* 2 *}$ \\
\hline 12. & Learning resources & $0.6059^{* * *}$ \\
\hline 13. & Physical facilities & $0.6181^{* * *}$ \\
\hline 14. & Interaction with co-teachers & $0.6016^{* *}$ \\
\hline 15. & Interaction with students & 0.1201 N.S \\
\hline
\end{tabular}

** Significant at 0.01 level of probability. $\quad$ Multiple R2 $=0.801$

* Significant at 0.05 level of probability

Table 4:- Regression coefficient between selected personal character-istics of teachers and their teaching styles of respondent teachers.

\begin{tabular}{|l|l|l|l|l|}
\hline S.No. & Independent Variable & $\begin{array}{l}\text { Regression } \\
\text { coefficient }\end{array}$ & Standard error & t-value \\
\hline 1. & Age & -0.4134 & 0.4293 & 0.9629 \\
\hline 2. & Designation & -5.1503 & 2.7903 & 1.8457 \\
\hline 3. & Gender & -2.5167 & 3.4343 & 0.7328 \\
\hline 4. & Academic qualification & 2.1669 & 3.0618 & 0.7077 \\
\hline 5. & Background & -2.1336 & 2.7903 & 0.7646 \\
\hline 6. & Teachers parental occupation & 1.6767 & 2.7319 & 0.6137 \\
\hline 7. & Teaching experience & 0.7225 & 0.2659 & $2.7174^{* *}$ \\
\hline 8. & Training received & -0.1176 & 0.0545 & $2.1590^{* *}$ \\
\hline 9. & Opinion towards model classroom & 0.9188 & 0.1785 & $5.1477^{* *}$ \\
\hline 10. & Use of teaching aids & -0.7410 & 0.7200 & 1.0291 \\
\hline 11. & Use of teaching methods & 0.8230 & 0.5664 & 1.4529 \\
\hline 12. & Learning resources & 0.8662 & 0.7175 & 1.2072 \\
\hline 13. & Physical facilities & -0.9853 & 0.6428 & 1.5330 \\
\hline 14. & Interaction with co-teachers & 2.1596 & 1.4475 & 1.4920 \\
\hline 15. & Interaction with students & 0.1922 & 0.3923 & 0.4899 \\
\hline
\end{tabular}

** Significant at 0.01 level of probability. 
Table 5:- Significance difference between selected characteristics of students and teachers.

\begin{tabular}{|l|l|l|}
\hline S.No. & Independent Variable & Z-value \\
\hline 1. & Gender & $0.0865 \mathrm{~N} \mathrm{~S}$ \\
\hline 2. & Background & $0.0451 \mathrm{~N} \mathrm{~S}$ \\
\hline 3. & Opinion towards model classroom & $1.6636 \mathrm{~N} \mathrm{~S}$ \\
\hline 4. & Learning resources & $7.6544^{* *}$ \\
\hline 5. & Physical facilities & $3.5233^{* *}$ \\
\hline 6. & Interaction with teachers & $19.8056^{* *}$ \\
\hline 7. & Interaction with students & $13.0584^{* *}$ \\
\hline
\end{tabular}

** Significant at 0.01 level of probability.

The significance of difference in selected characteristics between teachers and students was tested " $Z$ " statistics and the results were presented in Table 5.

The following characters have significant relationship between students and teachers viz., learning resources, physical facilities, interaction with teachers, interaction with students. At the same time gender, background, opinion towards model classroom were non significant in relation between teachers and students.

\section{Bibliography:-}

1. Cano J and Porter T 1997 The relationship between learning styles, academic major, and academic performance of Agriculture students Proceedings of the 24th Annual National Agricultural Education Research Meeting p.373-380 Las Vegas N V.

2. Grasha Anthony F 1996 Teaching with style, Alliance Publishers, Pittsburgh, USA.

3. Options in Classroom Technology for the Year 2000, Larry Gilbert, January, 1999. E-mail: Larry.Gilbert@wwu.edu.

4. McCollin E 2000 Faculty and student perceptions of teaching styles Do teaching styles differ for traditional and non traditional students Paper presented at the annual meeting of the Mid South Educational Research Associaton, Bowling Green KY.

5. McCollin E 2000 Faculty and student perceptions of teaching styles Do teaching styles differ for traditional and non traditional students Paper presented at the annual meeting of the Mid South Educational Research Associaton, Bowling Green KY.

6. Owu C 1992 Learning Styles of Post secondary Students Enrolled in Vocational Technical Institutes. Journal of Industrial Teacher Education 36 (4): National Association of Industrial and Technical Teacher Educators (ISSN 0022-1864).

7. Www.classrooms.com.

8. Reddy K G 2002 Training environment as perceived by the trainers of agricultural training institutes unpublished Ph.D. Thesis submitted to ANGRAU, Hyderabad

9. Schmeck R R and Grove 1979 Achievement and individual differences in learning processes Applied psychological measurement Vol 3(1), 43-49.

10. Schroeder Charles C 1993 New Students - New Learning Styles http://www.virtualschool.edu/mon.

11. Torres R M 1993 The cognitive ability and learning style of students enrolled in the college of Agriculture at the Ohio State University Unpublished doctoral dissertation The Ohio State University, Columbus 